\title{
Nocardioides, a New Genus of the Order Actinomycetales
}

\author{
H. PRAUSER \\ Akademie der Wissenschaften der DDR, Forschungszentrum für Molekularbiologie und Medizin, \\ Zentralinstitut für Mikrobiologie und experimentelle Therapie, Jena, German Democratic Republic
}

The properties of 17 strains of a nocardioform actinomycete isolated from soil are described. The hyphae of the primary mycelium of this organism fragment into irregular to rod- to coccus-like elements. The hyphae of the aerial mycelium fragment into rod- to coccus-like elements with smooth surfaces. These elements give rise to new mycelia. The organism is a gram-positive, non-acid-fast, aerobic, mesophile, and it has a cell wall composition of type I (LL-diaminopimelic acid, alanine, glutamic acid, glycine). The deoxyribonucleic acid base composition is $66.5 \mathrm{~mol} \% \mathrm{G}+\mathrm{C}$. The actinomycete is susceptible to phages of a taxon-specific set. Polyvalent Nocardia and Streptomyces phages are not propagated in the nocardioform organism, which is here regarded as belonging to a new genus, Nocardioides, the type species of which is $N$. albus. The type strain of $N$. albus is IMET 7807 (Culture Collection of the Zentralinstitut für Microbiologie und experimentelle Therapie, Jena). It has been deposited in the American Type Culture Collection under the number 27980 . The new genus is placed in the family Streptomycetaceae.

In a paper presented at a symposium on $\mathrm{No}$ cardia held during the 10th International Association of Microbiological Societies Congress at Mexico City in 1970, Prauser introduced the generic name Nocardioides, with type species $N$. albus, for an organism which, although widely distributed in soil, could not be identified with any other organism known at the time. The main characters were reported, and cultures of the organism were subsequently sent to a number of specialists for study with the hope that a suitable taxonomic niche could be found for this nocardioform actinomycete. Lechevalier et al. (6) included Nocardioides in their key to the genera of the actinomycetes, and subsequently Prauser received requests to effect the valid publication of names for the genus and its type species, Nocardioides and $N$. albus not having been previously validly published. It is the intent of this paper to satisfy these requests.

\section{MATERIALS AND METHODS}

Bacterial strains. From a total of about 60 freshly isolated strains, 17 were studied in detail: IMET 7801 (kaolin prepared for the ceramic industry), IMET 7802 and IMET 7803 (savanna on laterite, Lalibela, Ethiopia), IMET 7804 and IMET 7805 (meadow, Csopak, Hungary), IMET 7807 and IMET 7808 (lavender field, Tihany peninsula, Hungary), IMET 7809 and IMET 7810 (leafy wood, Tihany peninsula, Hungary), IMET 7812 (garden, Cabo Maisi, Prov. Oriente, Cuba), IMET 7813 (soil under a former charcoal pile, Cupeyal, Prov. Oriente, Cuba), IMET 7814 (rhizosphere on tephra, Surtur I, Surtsey, Iceland), IMET 7815 and IMET 7820 (gyttja sediment, valley of Altmühl river near Badanhausen, Federal Republic of Germany), IMET 7817 and IMET 7818 (limestone tuff, Tihany peninsula, Hungary), and IMET 7819 (grassland, Schwellenburg Hill near Erfurt, German Democratic Republic). (IMET is the abbreviation for Culture Collection of the Zentralinstitut für Mikrobiologie und experimentelle Therapie, Jena.)

Two Arthrobacter strains were also studied: Arthrobacter simplex NCIB 8929 and a strain of this species received under the name Arthrobacter globiformis from the Science Service, Bacteriology Division, Ottawa, Canada (its number in our collection is IMET SG 1020).

Phages. The phages used were those isolated by Prauser and Falta (20); Streptomyces phages S5, S6, $\mathrm{S} 7$, and $\mathrm{S} 8$, phages $\mathrm{X} 5$ and $\mathrm{X6}$, Nocardia phages N6, N7, N8, and N9, Oerskovia phage 04, Promicromonospora phage P3, and Micromonospora phages $\mathrm{Mm} 3$ and $\mathrm{Mm} 4$, all isolated from soil by the author (19), were also included in this study.

Media. Cultures of the strains studied were isolated from soil by use of the agar double-layer method, in which dilutions of soil suspensions are mixed in the melted agar used for the upper layer. The isolation media were those commonly used, such as inorganic salts-starch agar (3) and arginineglycerol-salt agar (2). Another medium used was one found suitable for the isolation of many actinomycetes, namely: oatmeal, $3.0 \mathrm{~g} ; \mathrm{KNO}_{3}, 0.2 \mathrm{~g}$; $\mathrm{K}_{2} \mathrm{HPO}_{4}, 0.5 \mathrm{~g} ; \mathrm{MgSO}_{4}, 0.2 \mathrm{~g}$; agar, $15.0 \mathrm{~g}$; and distilled water, $1,000 \mathrm{ml} ; \mathrm{pH}, 7.0$.

The test media used for the study of the strains were those of the International Streptomyces Project (22), glucose asparagine agar (8), and chitin agar $\left(\mathrm{KCl}, 0.5 \mathrm{~g} ; \mathrm{K}_{2} \mathrm{HPO}_{4}, 1.0 \mathrm{~g} ; \mathrm{MgSO}_{4}, 0.5 \mathrm{~g} ; \mathrm{FeSO}_{4}\right.$, $0.01 \mathrm{~g}$; chitin, $1.0 \mathrm{~g}$; agar, $15.0 \mathrm{~g}$; and distilled water, $1,000 \mathrm{ml} ; \mathrm{pH}, 7.0$ ). The production of melanoid pigments and the utilization of carbon sources were 
also determined according to the instructions of the International Streptomyces Project (22); however, with regard to the prompt development of the strains under study, the plates with the carbon sources were checked for growth after 5 and 12 days of incubation. Hydrolysis of starch was determined by the method used by Gause et al. (3). For the determination of $\mathrm{H}_{2} \mathrm{~S}$ production, an agar medium was used containing $1.0 \mathrm{~g}$ of cysteine, $1.0 \mathrm{~g}$ of yeast extract, $6.0 \mathrm{~g}$ of $\mathrm{NaCl}, 1.0 \mathrm{~g}$ of mannose, $15.0 \mathrm{~g}$ of agar, and $1,000 \mathrm{ml}$ of distilled water $(\mathrm{pH} \mathrm{7.0)}$. The medium was poured in 1-ml portions into tubes 1 by $10 \mathrm{~cm}$ in size. Paper strips impregnated with lead acetate solution were fixed directly above the agar surfaces which had been inoculated with the strains to be tested. Browning or blackening of the strips was read as a positive result; readings were made after 2 and 4 days of incubation.

Cell-wall analysis. The diamino acids of the cell walls were determined by the method of Becker et al. (1), and the sugars were determined by the technique of Murray and Proctor (12). Pure cell wall preparations were obtained by the method of Yamaguchi (24) for the determination of the amino acids of the cell wall peptidoglycan. Nocardomycolic acids (lipid LCN-A) were detected by the technique of Mordarska (11).

Determination of DNA base composition. The guanine plus cytosine $(\mathrm{G}+\mathrm{C})$ content of the deoxyribonucleic acid (DNA) was determined by the method of Marmur and Doty (9) using the $T_{m}$ value determination.

Phage testing. The strains to be tested for sensitivity to phages were cultivated on agar slants using a modification of complex organic medium M 79 (20), in which the casein hydrolysate was replaced by $2.0 \mathrm{~g}$ of Casamino Acids (Difco) and the tap water was replaced by distilled water. After 1 to 5 days, the growth was suspended in $3 \mathrm{ml}$ of liquid modified medium M 79. The suspension was mixed with $60 \mathrm{ml}$ of melted solid medium M 79 at approximately $48 \mathrm{C}$, and the mixture was poured into square dishes (16-cm sides) to a depth of $2.3 \mathrm{~mm}$. The number of bacterial cells per milliliter was not standardized because it had been found that variations in cell number did not influence the results. The uncovered dishes were dried for $1 \mathrm{~h}$ at $28 \mathrm{C}$. The phage suspensions (approximately $1 \times 10^{8}$ plaque-forming units per $\mathrm{ml}$ ) were transferred to the plates by the use of a homemade multi-transferer which, in one step, allows 64 droplets of about $0.006 \mathrm{ml}$ to be deposited on an agar surface. The plates were incubated at $28 \mathrm{C}$. All phage suspensions were applied in duplicate in each test, and each test was repeated one or more times. From clear areas on the plates, inocula were transferred with a loop to other plates with identical bacterial strains. Lysis on these plates after $24 \mathrm{~h}$ was considered proof that the clearings on the original plates were caused by phages.

\section{RESULTS}

Distribution. More than 60 strains of the actinomycete under discussion have been isolated. Seventeen were selected for the present study. These strains represent the majority of the source materials from which the organism was isolated. It was the predominant microorganism in a sample of kaolin prepared for the ceramic industry, it was frequently found in a gyttja sediment, and it was repeatedly isolated from several soils of the Balaton region in Hungary. From the other samples, as a rule only one or two strains could be obtained. All in all, the organism seems to be rare but widely distributed. Obviously, there is a preference for special ecological conditions which, however, have not been defined.

Gross appearance. Organisms of the kind under study were easily observed, after some practice, on the isolation plates even though striking characteristics were lacking. The pasty colonies are whitish to faint yellowish-brown and may have smooth to wrinkled and dull to bright surfaces. Most distinctive of the organism was a very thin, chalky aerial mycelium which appeared a few days after the colonies became visible. Many strains tended to lose the capacity to form aerial mycelium in the course of continued cultivation. For example, strain IMET 7801, the first isolate and the strain provisionally selected to serve as the type strain, no longer produces aerial mycelium.

The organism grows on the standard media used for the cultivation of bacteria, including actinomycetes. Colonies appear 1 or 2 days after incubation at $28 \mathrm{C}$ and develop quickly. The formation of aerial mycelium was usually good on yeast extract-malt extract agar, oatmeal agar, and glucose-asparagine agar, fair on inorganic salts-starch agar and glycerol-asparagine agar, and absent on the complex organic medium. Soluble pigments were not produced.

Morphology and developmental cycle. The hyphae of the primary mycelium, 0.5 to 0.8 $\mu \mathrm{m}$ in diameter, grow on the agar surface or penetrate the agar and branch abundantly (Fig. 1). They fragment into irregular to rodor coccus-like elements (Fig. 1). The hyphae of the aerial mycelium, 0.6 to $1.0 \mu \mathrm{m}$ in diameter, either do not branch or are sparsely and irregularly branched, thus resembling the structure of the aerial mycelium of nocardiae (Fig. 2). The aerial hyphae fragment into rod- to coccus-like elements (Fig. 3) with smooth surfaces (Fig. 4). The elements of both the primary and the aerial mycelium give rise to new mycelia by extruding one or two hyphae.

Physiological characters. The organism is aerobic and mesophilic. The optimum temperature for growth is about $28 \mathrm{C}$; growth is also good at 18 and $37 \mathrm{C}$, but it does not occur at 50 C. D-Glucose, L-arabinose, D-xylose, D-mannitol, D-fructose, and rhamnose are utilized 


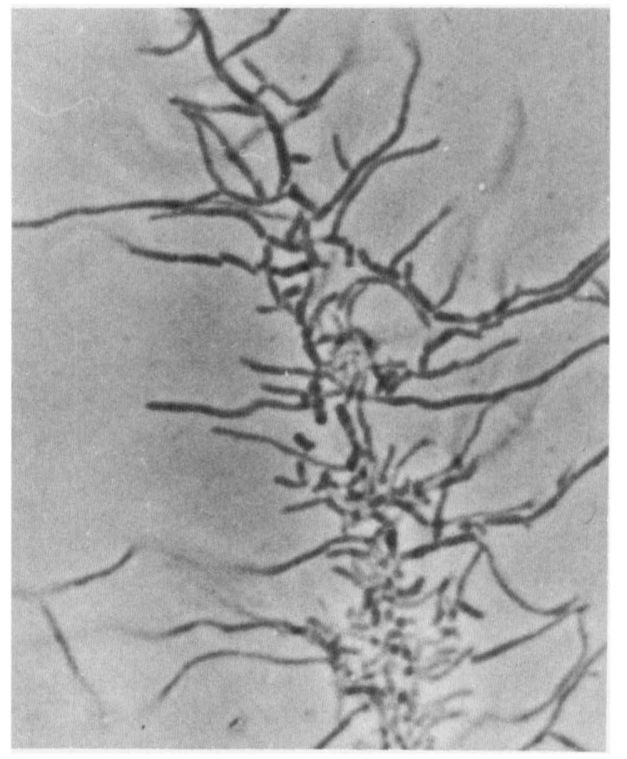

FIG. 1. Beginning of fragmentation of primary mycelium of Nocardioides albus IMET 7807 on glycerol-asparagine agar. Seven days. $\times 1,400$.

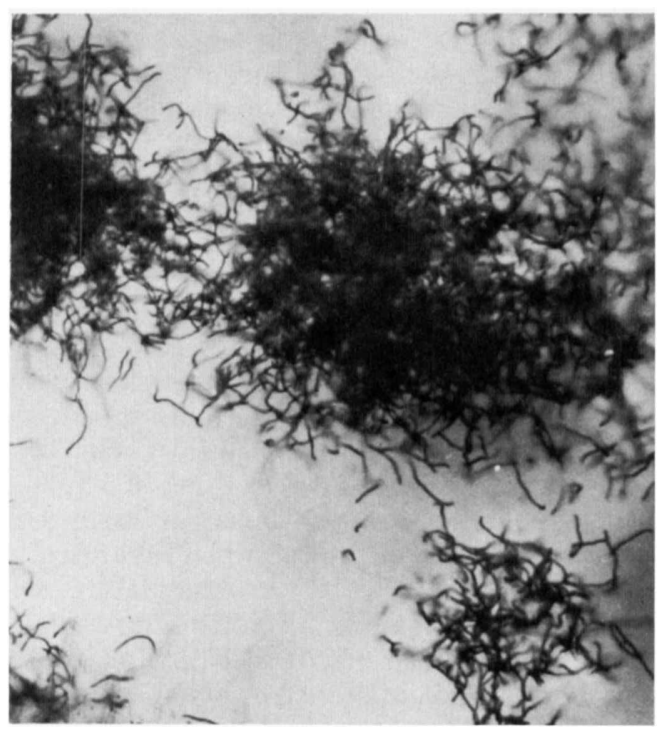

Fig. 2. Aerial mycelium of Nocardioides albus IMET 7807 on chitin agar. Eleven days. $\times 250$.

for growth. Sucrose is utilized by most strains. Raffinose is very rarely utilized and iso-inositol is not utilized (Table 1). Melanoid pigments are not formed. Starch is hydrolyzed. Strains IMET 7815 and IMET 7819 hydrolyze starch after 7 days but only directly below the colony. $\mathrm{H}_{2} \mathrm{~S}$ is produced.

Biochemical characters. The organism is gram-positive and non-acid-fast.
INT. J. Syst. BaCteriol.

The overall cell wall composition of the 17 strains is of type I according to the classification of Lechevalier et al. (6). The primary structure of the peptidoglycan of strain IMET 7807 is of the LL-Dpm-Gly type containing LL-diaminopimelic acid in the peptide and one molecule of glycine in the interpeptide bridge. Strains IMET 7801, IMET 7803, IMET 7805, IMET 7807, IMET 7808, IMET 7813, IMET 7814, and IMET 7815 were studied with regard to nocardomycolic acids by the method of Mordarska (11). Nocardomycolic and other mycolic acids were lacking in all of these strains. Nocardomycolic acids were not detected in strain IMET 7807 by the methanolysis method of Minnikin et al. (10). The DNA base composition of one strain, IMET 7801, was found to be $66.5 \mathrm{~mol} \% \mathrm{G}+\mathrm{C}$.

Phage susceptibility. All of the strains studied were susceptible to at least one of the six X-phages; two strains proved susceptible to all of the phages (Table 2). Phage X1 is the most suitable for phage typing the organism under study. (Phage X1 is available from the IMET Culture Collection, Jena.) In recent studies, phages which previously had been active against specific strains no longer caused lysis (Table 2) or caused clearings only.

None of the strains studied were susceptible to the Streptomyces phages S1, S2, S3, S4, S6, $\mathrm{S} 7$, and S8, the Nocardia phages N2, N3, N4, N5, N6, N7, N8, and N9, the Oerskovia phages $\mathrm{O} 2$, $\mathrm{O} 3$, and $\mathrm{O} 4$, the Promicromonospora phages P1, P2, and P3, the Micromonospora phages $\mathrm{Mm} 1, \mathrm{Mm} 2, \mathrm{Mm} 3$, and $\mathrm{Mm} 4$ and the Arthrobacter phage A1 $(9,19 a, 20 ; \mathrm{H}$. Prauser, unpublished data). In some cases, spotting of S-phage suspensions, especially of S7, on plates inoculated with the strains under study pro-

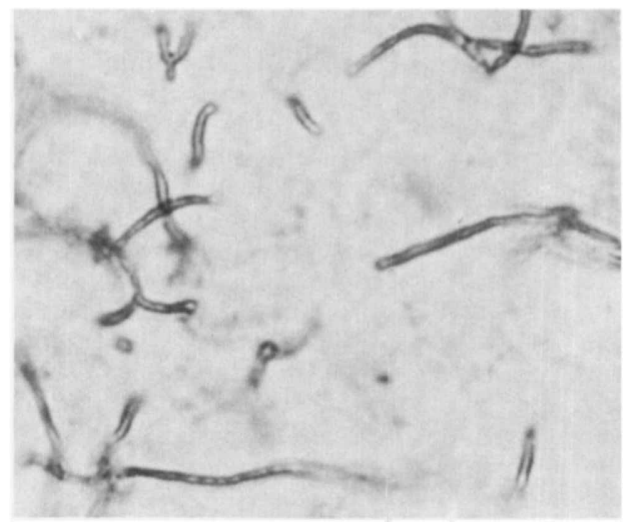

Fig. 3. Aerial hyphae of Nocardioides albus IMET 7807 growing directly out of yeast extractmalt extract agar and showing fragmentation. Eleven days. $\times 1,250$. 


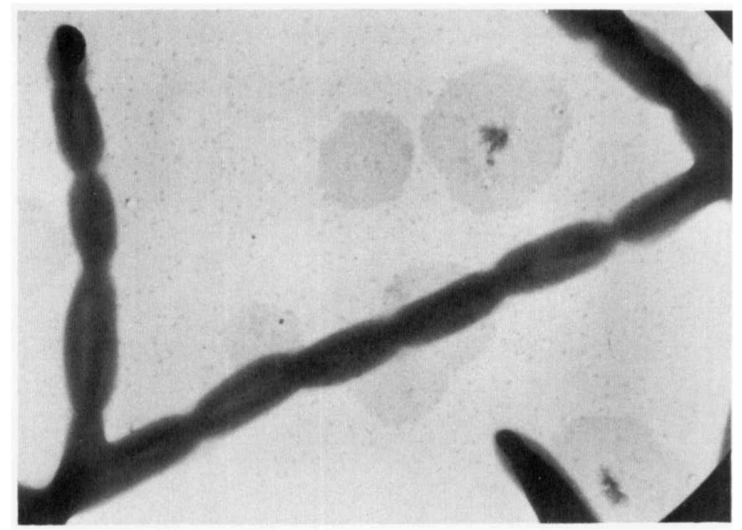

FIG. 4. Electron micrograph of aerial hyphae of Nocardioides albus IMET 7807 fragmented into sporelike elements from yeast extract-malt extract agar. Fourteen days. $\times 10,000$.

duced clearings in the bacterial lawn; however, the production of new phages could not be shown.

On the other hand, X-phages were unable to lyse strains of 19 genera of the order Actinomycetales (19). Phage X6 was active against strains under study and against Arthrobacter simplex NCIB 8929 and Arthrobacter sp. IMET SG 1020, which resembles strains of Arthrobacter simplex. Phage $\mathrm{X} 4$ was effective against the latter strain and the strains under study, but it caused only a slight clearing without propagation in NCIB 8929. The cell walls of both Arthrobacter strains contain LL-diaminopimelic acid and glycine.

Taxonomy. As gram-positive, truly branching bacteria, the organisms under study are placed in the order Actinomycetales as recently defined by Gottlieb (4). According to their cell wall composition, these organisms are most closely related to the members of the family Streptomycetaceae. However, they are differentiated from members of Streptomyces and from members of the other genera of the family primarily by their developmental cycle and their morphology. In contrast to streptomycetes, the study organisms are typically nocardioform; i.e., they reproduce solely by fragmentation of their hyphae, either all or in part, into irregular to rod-like to coccoid elements $(19,19 a)$. The spores are not produced in or on special parts of the mycelium as in the rule in Streptomyces.

Moreover, the strains studied were lysed only by the taxon-specific X-phages, which do not attack any streptomycetes $(19,20)$.

Thus, a new genus, Nocardioides, is proposed to harbor the organism, which is here proposed as a new species, $N$. albus.

Nocardioides gen. nov. (M.L. fem.n. Nocardia name of a genus in the order Actinomyce- tales; Gr. n. idus form; M.L. mas.n. Nocardioides Nocardia-like; intended to refer to the morphological similarity between members of the two genera.)

The branching hyphae of the primary mycelium grow on the agar surface or penetrate the agar and fragment into irregular to rod- to coccus-like elements. The hyphae of the aerial mycelium fragment into rod- to coccus-like elements. The elements of both mycelia grow out to new mycelia. No motile cells are produced.

Gram-positive, non-acid-fast, aerobic. Cell wall composition of type I (LL-diaminopimelic acid, alanine, glutamic acid, glycine), with a primary structure of the LL-Dap-Gly type. Nocardomycolic acids are not produced.

Type species: Nocardioides albus sp. nov.

Nocardioides albus sp. nov. (L. adj. albus white). The hyphae of the primary mycelium, 0.5 to $0.8 \mu \mathrm{m}$ in diameter, fragment into irregular to rod- to coccus-like elements. The hyphae of the aerial mycelium, 0.6 to $1.0 \mu \mathrm{m}$ in diameter, fragment into rod- to coccus-like elements with smooth surfaces.

The primary mycelium on oatmeal agar, yeast extract-malt extract agar, glucose-asparagine agar, and other agar media is whitish to faintly yellowish; in aged cultures, it is whitish to faintly brownish. Colonies are pasty, with smooth to wrinkled and dull to bright surfaces. No soluble pigments are produced. In aged cultures, faint brownish soluble pigments may occur. The aerial mycelium is very thin, dense, and chalky.

Gram-positive, non-acid-fast, aerobic, mesophilic. Optimum temperature for growth, $28 \mathrm{C}$; good growth occurs at 18 and $37 \mathrm{C}$; there is no growth at $50 \mathrm{C}$. Grows on media ordinarily used for the cultivation of bacteria, especially actinomycetes.

Cell wall composition is of type I (LL-di- 
TABLE 1. Utilization of carbon sources for growth ${ }^{a}$ by strains of Nocardioides albus

\begin{tabular}{|c|c|c|c|c|c|c|c|c|}
\hline \multirow[b]{2}{*}{ Strains } & \multicolumn{8}{|c|}{ Utilization of carbon sources for growth } \\
\hline & $\begin{array}{l}\text { L-Arabi- } \\
\text { nose }\end{array}$ & Sucrose & D-Xylose & $\begin{array}{l}\text { Iso-inosi- } \\
\text { tol }\end{array}$ & $\begin{array}{c}\text { D-Manni- } \\
\text { tol }\end{array}$ & $\begin{array}{l}\text { D-Fruc- } \\
\text { tose }\end{array}$ & $\begin{array}{l}\text { Rham- } \\
\text { nose }\end{array}$ & Raffinose \\
\hline \multirow[t]{2}{*}{ IMET 7801} & ++ & - & + & - & ++ & ++ & ++ & - \\
\hline & ++ & - & ++ & - & ++ & ++ & ++ & - \\
\hline \multirow[t]{2}{*}{ IMET 7802} & ++ & ++ & + & - & ++ & + & ++ & - \\
\hline & ++ & ++ & ++ & - & $+t$ & ++ & ++ & - \\
\hline \multirow[t]{2}{*}{ IMET 7803} & ++ & ++ & + & - & ++ & ++ & $+t$ & - \\
\hline & ++ & ++ & ++ & - & ++ & ++ & ++ & + \\
\hline \multirow[t]{2}{*}{ IMET 7804} & ++ & $+t$ & + & - & ++ & ++ & ++ & - \\
\hline & ++ & ++ & ++ & - & ++ & ++ & ++ & - \\
\hline \multirow[t]{2}{*}{ IMET 7805} & ++ & - & + & - & ++ & + & ++ & + \\
\hline & ++ & \pm & ++ & - & ++ & ++ & ++ & $+t$ \\
\hline \multirow[t]{2}{*}{ IMET 7807} & ++ & \pm & + & - & ++ & ++ & ++ & - \\
\hline & ++ & ++ & ++ & - & ++ & ++ & $+t$ & - \\
\hline \multirow[t]{2}{*}{ IMET 7808} & ++ & \pm & + & - & ++ & ++ & $+t$ & - \\
\hline & ++ & ++ & $+t$ & - & ++ & ++ & ++ & + \\
\hline \multirow[t]{2}{*}{ IMET 7809} & ++ & \pm & + & - & ++ & ++ & ++ & - \\
\hline & ++ & + & ++ & - & ++ & ++ & ++ & + \\
\hline \multirow[t]{2}{*}{ IMET 7810} & ++ & - & + & - & ++ & ++ & $+t$ & - \\
\hline & ++ & \pm & ++ & - & ++ & ++ & ++ & - \\
\hline \multirow[t]{2}{*}{ IMET 7812} & ++ & ++ & + & - & ++ & ++ & $+t$ & - \\
\hline & ++ & ++ & ++ & - & ++ & ++ & ++ & - \\
\hline \multirow[t]{2}{*}{ IMET 7813} & $+t$ & ++ & + & - & ++ & $+t$ & ++ & - \\
\hline & ++ & ++ & ++ & - & ++ & ++ & ++ & - \\
\hline \multirow[t]{2}{*}{ IMET 7814} & ++ & + & + & - & $+t$ & ++ & ++ & - \\
\hline & ++ & ++ & ++ & - & ++ & ++ & ++ & - \\
\hline \multirow[t]{2}{*}{ IMET 7815} & ++ & ++ & + & - & ++ & $+t$ & ++ & - \\
\hline & ++ & ++ & ++ & - & $+t$ & ++ & ++ & - \\
\hline \multirow[t]{2}{*}{ IMET 7817} & ++ & + & + & - & ++ & ++ & ++ & - \\
\hline & ++ & ++ & ++ & - & ++ & ++ & ++ & - \\
\hline \multirow[t]{2}{*}{ IMET 7818} & ++ & ++ & ++ & - & $+t$ & ++ & ++ & - \\
\hline & ++ & ++ & ++ & - & ++ & ++ & ++ & - \\
\hline \multirow[t]{2}{*}{ IMET 7819} & ++ & - & + & - & $+t$ & ++ & ++ & - \\
\hline & ++ & + & ++ & - & ++ & ++ & ++ & - \\
\hline \multirow[t]{2}{*}{ IMET 7820} & ++ & ++ & + & - & $+t$ & ++ & ++ & - \\
\hline & ++ & $+t$ & ++ & - & ++ & ++ & ++ & - \\
\hline
\end{tabular}

a Method according to reference 22 except that observations were made 5 (first lines) and 12 (second lines) days after inoculation. Growth on basal medium without carbon source (negative control) always lacking or extremely weak. Growth on D-glucose (positive control) always very good. There were no differences between the duplicate plates. Symbols: ++ , strongly positive utilization (growth similar to or greater than on D-glucose); + , utilization (growth somewhat less than on D-glucose); \pm , doubtful utilization (growth slightly better than on basal medium without carbon source); -, no utilization (growth similar to growth on basal medium without carbon source). 
TABLE 2. Host ranges of Nocardioides phages"

\begin{tabular}{lcccccc}
\hline \multirow{2}{*}{$\begin{array}{c}\text { Nocardioides al } \\
\text { bus strains }\end{array}$} & \multicolumn{7}{c}{ Host ranges of Nocardioides phages } \\
\cline { 2 - 7 } & $\mathrm{X} 1$ & $\mathrm{X} 2$ & $\mathrm{X3}^{b}$ & $\mathrm{X} 4$ & $\mathrm{X} 5$ & $\mathrm{X} 6$ \\
\hline IMET 7801 & + & + & 0 & 0 & + & + \\
IMET 7802 & + & + & - & - & 0 & + \\
IMET 7803 & + & 0 & - & - & + & + \\
IMET 7804 & + & 0 & - & 0 & + & + \\
IMET 7805 & + & - & - & 0 & + & + \\
IMET 7807 & + & + & - & - & + & 0 \\
IMET 7808 & + & - & - & - & + & + \\
IMET 7809 & 0 & + & 0 & - & 0 & 0 \\
IMET 7810 & 0 & + & + & 0 & 0 & + \\
IMET 7812 & + & + & + & + & + & 0 \\
IMET 7813 & + & + & + & 0 & + & + \\
IMET 7814 & + & + & - & 0 & + & + \\
IMET 7815 & + & + & + & + & + & + \\
IMET 7817c & + & + & - & - & + & - \\
IMET 7818c & - & + & - & - & - & + \\
IMET 7819c & + & + & + & + & + & + \\
IMET 7820 & + & - & - & 0 & + & + \\
NCIB 8929 & - & - & - & $-d$ & - & + \\
SG 1020 & - & - & - & + & - & +
\end{tabular}

"Symbols: +, lysis; -, no lysis; 0 , no lysis to date, but lysis in previous studies.

${ }^{b}$ Only partly included in former comparative studies.

${ }^{c}$ Not included in former comparative studies.

${ }^{d}$ Only a clearing effect without phage propagation.

aminopimelic acid, alanine, glutamic acid, and glycine). Nocardomycolic acids are lacking. The DNA base composition is $66.5 \mathrm{~mol} \% \mathrm{G}+\mathrm{C}$.

Melanoid pigments were not produced by any of the 17 strains, but starch was hydrolyzed and $\mathrm{H}_{2} \mathrm{~S}$ was produced by all of them. D-Glucose, L-arabinose, D-xylose, D-mannitol, D-fructose, and rhamnose were utilized for growth by all of the strains. Sucrose was utilized by most of the strains (14/17), raffinose was utilized by very few of the strains (4/17), and iso-inositol was not utilized by any of them.

Susceptible to one or more of the X-phages.

Habitat, soil.

Type strain. The type strain, IMET 7807 , has been deposited under this number with the Culture Collection of the Zentralinstitut für Mikrobiologie und experimentelle Therapie, Jena. This strain has also been deposited in the American Type Culture Collection, Rockville, Md., under the number 27980.

The type strain was isolated from soil of a lavender field, Tihany peninsula, Balaton region, Hungary.

The strain displays the characters given in the species description. Aerial mycelium is produced on yeast extract-malt extract agar, glucose-asparagine agar, oatmeal agar, and less distinctly on inorganic salts-starch agar. The utilization of carbohydrates by this strain is presented in Table 1 and the susceptibility to X-phages is presented in Table 2. The DNA base composition of this strain was not studied.

Originally the organism described here was referred to by Prauser $(14,15)$ as strain IMET 7801 , which was the first isolate. Later, Prauser (16-18) spoke of the "IMET 7801 group," which harbored the bacteria here placed in Nocardioides albus. Strain IMET 7801 was initially intended to serve as the type strain. However, since it lost the capacity to form aerial mycelium, it was rejected in favor of strain IMET 7807, which had previously been studied by Prauser and Falta (20) under the strain number 652-48.

\section{DISCUSSION}

Ten years ago the organism described here undoubtedly would have been placed in the genus Nocardia. Now, the knowledge and taxonomic interpretation of differing cell wall compositions no longer permit this grouping. Among the LL-diaminopimelic acid-containing actinomycetes, Nocardioides is distinctly different from the other genera. Sporichthya polymorpha Lechevalier et al. (7) lacks a primary mycelium and propagates by motile elements resulting from the fragmentation of the aerial hyphae. Intrasporangium calvum Kalakoutskii et al. (5) also lacks aerial mycelium, forms vesicles which were called sporangia (5), and does not utilize the carbon sources which promote the growth of Nocardioides albus except for D-glucose (unpublished data). Arachnia propionica (Buchanan and Pine) Pine and Georg (13) does not form aerial mycelium and is facultatively anaerobic. Preliminary results on the primary structure of its peptidoglycan indicate that the peptide unit differs from that of Nocardioides albus and of the other $\mathrm{LL}_{-} \mathrm{di}_{\overline{-}}$ aminopimelic acid-containing actinomycetes by the replacement of the L-alanine in position 1 by glycine (21).

Nocardioides albus corresponds completely to the definition of nocardioform organisms $(19,19 a)$. These organisms are considered to represent a developmental cycle intermediate between the cycle of the coryneform bacteria and that of the sporoactinomycetes, which were defined as producing spores in or on definite parts of the mycelium (19a). The term "nocardioform organisms" neither denotes a taxon nor replaces the phrase "actinomycetes with fragmenting primary mycelium." For example, a spore-producing streptomycete displaying some 
fragmentation of the primary mycelium remains a sporoactinomycete because of its well defined spore formation which, as a rule, occurs in or on special parts of the aerial mycelium.

Of special interest is the susceptibility of two Arthrobacter simplex strains to Nocardioides phages X4 and X6. Arthrobacter simplex NCIB 8929 , included in this study, was classified by Yamada and Komagata (23) in their group 6. This group is characterized by the presence of LL-diaminopimelic acid in the cell wall, a DNA base composition of 70 to $72 \mathrm{~mol} \% \mathrm{G}+\mathrm{C}$, a bending type of cell division, and elongated, even branching cells. Yamada and Komagata concluded that bacteria of this group, which do not appear to belong to any of the presently recognized genera, seem to be related to Streptomyces. Schleifer and Kandler (21) discuss the relationship of coryneforms like Arthrobacter simplex to actinomycetes of identical cell wall composition. The results of the actinophage host range studies seem to confirm the relationship of these LL-diaminopimelic acid-containing coryneforms to actinomycetes of a cell wall composition of type I. Moreover, Nocardioides albus represents a morphological intermediate between coryneforms and streptomycetes.

If the morphological and biochemical evidence is taken into consideration, an evolutionary line originating with coryneforms and culminating with sporoactinomycetes, like the streptomycetes, and including nocardioform intermediates like Nocardioides albus, might be considered (19a). Such considerations are, of course, highly speculative. Nevertheless, they may be of help in finding a family position for the genus Nocardioides. Though Nocardioides albus markedly differs from any streptomycete in morphology and phage susceptibility, it seems reasonable to place the genus in the family Streptomycetaceae Waksman and Henrici, where it was provisionally placed by Lechevalier et al. (6). The identical cell wall composition, the formation of primary and aerial mycelium, the slight sensitivity of Nocardioides albus strains to Streptomyces phages, and the possibility of a close evolutionary relationship between Nocardioides and Streptomyces may be reasons enough for this proposal. The inclusion of nocardioform organisms in the family Streptomycetaceae will, of course, present difficulties to future attempts at defining this family.

\section{ACKNOWLEDGMENTS}

I thank W. Schwarz, Braunschweig, for the soil samples from Ethiopia, Iceland, and the Federal Republic of Germany; M. Schmiedeknecht, Aschersleben, for those from Cuba; M. Goodfellow, Newcastle upon Tyne, for making available strains of coryneform bacteria and for the analyses for nocardomycolic acid in strain IMET 7807; 0 . Kandler, Munich, for studying the primary structure of the peptidoglycan; Chr. Zimmer, Jena, for the G+C determination of the DNA; and D. Tille, Jena, for the analyses of nocardomycolic acids. The excellent technical assistance of Elisabeth Prauser and Eva Woitzik is greatly appreciated.

\section{LITERATURE CITED}

1. Becker, B., M. P. Lechevalier, R. E. Gordon, and H. A. Lechevalier. 1964. Rapid differentiation between $\mathrm{No}$ cardia and Streptomyces by paper chromatography of whole-cell hydrolysates. Appl. Microbiol. 12:421423.

2. El-Nakeeb, M. A., and H. A. Lechevalier. 1963. Selective isolation of aerobic actinomycetes. Appl. Microbiol. 11:75-77.

3. Gause, G. F., T. P. Preobrazhenskaya, E. S. Kudrina, N. O. Blinov, I. D. Rjabova, and M. A. Sveshnikova. 1957. Problems pertaining to the classification of actinomycetes-antagonists (in Russian). Medgiz, Moscow.

4. Gottlieb, D. 1974. Order I. Actinomycetales Buchanan 1957, 162. p. 657-881. In R. E. Buchanan and N. E. Gibbons (ed.), Bergey's manual of determinative bacteriology, 8th ed. Williams and Wilkins Co., Baltimore.

5. Kalakoutskii, L. V., I. Kirillova, and N. A. Krasil'nikov. 1967. A new genus of the ActinomycetalesIntrasporangium gen. nov. J. Gen. Microbiol. 48: 79-85.

6. Lechevalier, H. A., M. P. Lechevalier, and N. N. Gerber. 1971. Chemical composition as a criterion in the classification of actinomycetes. Adv. Appl. Microbiol. 14:47-72.

7. Lechevalier, M. P., H. A. Lechevalier, and P. E. Holbert. 1968. Sporichthya, un nouveau genre de Streptomycetaceae. Ann. Inst. Pasteur Paris 114:277-286.

8. Lindenbein, W. 1952. Über einige chemisch interessante Actinomycetenstämme und ihre Klassifizierung. Arch. Mikrobiol. 17:361-383.

9. Marmur, J., and P. Doty. 1962. Determination of the base composition of deoxyribonucleic acid from its thermal denaturation temperature. J. Mol. Biol. 5: 109-118.

10. Minnikin, D. E., P. V. Patel, and M. Goodfellow. 1974. Mycolic acids of representative strains of Nocardia and the "rhodochrous" complex. FEBS Lett. 39:322324.

11. Mordarska, H. 1968. A trial of using lipids for the classification of actinomycetes. Arch. Immunol. Ther. Exp. 16:45-50.

12. Murray, I. G., and A. G. J. Proctor. 1965. Paper chromatography as an aid to the identification of Nocardia species. J. Gen. Microbiol. 41:163-167.

13. Pine, L., and L. K. Georg. 1969. Reclassification of Actinomyces propionicus. Int. J. Syst. Bacteriol. 19:267-272.

14. Prauser, H. 1966. New and rare actinomycetes and their DNA base composition. Publ. Fac. Sci. Univ. J. E. Purkyné Brno K38:268-270.

15. Prauser, H. 1967. Contributions to the taxonomy of the Actinomycetales. Publ. Fac. Sci. Univ. J. E. Purkyné Brno K40:196-199.

16. Prauser, H. 1968. State and tendencies in the taxonomy of Actinomycetales. Publ. Fac. Sci. Univ. J. E. Purkyné Brno K43:295-312.

17. Prauser, H. 1970. Characters and genera arrangement in the Actinomycetales, p. 407-418. In H. Prauser (ed.), The Actinomycetales. VEB Gustav Fischer, Jena. 
18. Prauser, H. 1970. Application of actinophages on taxonomy of Actinomycetales. Publ. Fac. Sci. Univ. J. E. Purkyné Brno K47:123-126.

19. Prauser, H. 1974. Host-phage relationships in nocardioform organisms, p. 84-85. In G. Brownell (ed.), Proceedings of the First International Conference on the Biology of Nocardiae. Merida. McGowen, Augusta.

19a. Prauser, H. 1975. The Actinomycetales - an order?, p. 19-33. In T. Hasegawa (ed.), Proc. 1st Congr. Int. Assoc. Microbiol. Soc., vol. 1. Science Council of Japan.

20. Prauser, H., and R. Falta. 1968. Phagensensibilität, Zellwandzusammensetzung und Taxonomie von Ac- tinomyceten. Z. Allg. Mikrobiol. 8:39-46.

21. Schleifer, K. H., and O. Kandler. 1972. Peptidoglycan types of bacterial cell walls and their taxonomic implications. Bacteriol. Rev. 36:407-477.

22. Shirling, E. B., and D. Gottlieb. 1966. Methods for characterization of Streptomyces species. Int. J. Syst. Bacteriol. 16:313-340.

23. Yamada, K., and K. Komagata. 1972. Taxonomic studies on coryneform bacteria. V. Classification of coryneform bacteria. J. Gen. Appl. Microbiol. 18: 417-431.

24. Yamaguchi, T. 1965. Comparison of the cell wall composition of morphologically distinct actinomycetes. J. Bacteriol. 89:444-453. 